\title{
Effect of various feeding frequencies on growth performance and previously starved fingerlings and juveniles of African catfish (Clarias gariepinus)
}

\author{
Mohsen Saleh Hussein \\ Department of Animal Production (Fish Production), Faculty of Agriculture, \\ Al-Azhar University, Egypt.
}

\begin{abstract}
Growth performance in fingerlings and juveniles of African catfish Clarias gariepinus, was examined after various feeding frequencies. Fish were first fed once, twice, thrice and four times daily over a period of 10 weeks before satiation feeding resumed for 12 weeks. Monthly changes in weight gain, feed intake, nutrient utilization and economy of production were monitored. No significant difference was observed in the feed conversion ratio and voluntary feed intake both at the juvenile and fingerling stages. Fish fed thrice a day recorded the highest mean weight gain but no significant differences were observed across the different feeding frequencies in the juvenile fish. The specific growth rate value of 0.69 and $0.63 \% /$ day was observed for the fingerlings and juveniles had the least value in fish that were fed four times a day, while no significant differences were observed in all economic parameters measured for the juveniles across the feeding levels. On the contrary fingerlings fed once were significantly different having the lowest values from those fed with other feeding levels in the investment cost analysis and gross profit. It can be concluded that the fish fed at once a day for a period of 10 weeks, can still catch-up with others fed at higher feeding frequencies when returned to satiation feeding.
\end{abstract}

Keywords: African catfish, feeding frequencies, growth performance, nutrient utilization, economy of production, feeding frequency.

\section{INTRODUCTION}

The African catfish (Clarias gariepinus), which often contaminate tilapia ponds in Egypt, have been recently investigated as a potential aquaculture species. Considerable effort has been made to investigate its reproductive biology (DeGroot, 1987). Feeding habits revaled that the fishes are mainly omnivorous, feeding on detritus, invertebrates, and small fishes; but the extent of its predatory ability is unknown (Pillay, 1990). Nile catfish plays an important role among freshwater species in the trophic chain, where tilapiaspecies were the most preferred food consumed by this food item especially the young ones followed by insects, crustaceans and molluscs, respectively (Khallaf and Gaber, 1991).

In the last few years, increased interests in aquaculture and polyculture has been witnessed due to spurred interests of many people in the fish farming, and this will continue to play an important role in meeting the demand for the fish (FAO, 2007 and Solomon and Boro, 2010).

Feeds and feeding habits of the larvae, fry and fingerlings of the catfishes have been most studied and shown to influence the growth and survival of the fish (Egborge and Chigbu, 1988; Ovie, 1996; Osuji et al., 2003; Olaleye, 2005; Adewumi and Olaleye , 2011).

Of the cannibalistic nature of $C$. gariepinus, multiple sorting is essential. As the fish grow, big ones ofthe same size-group are removed to another tank forrearing. 
Thus harvesting is done at different periods forthe different groups sorted. Polyculture of $C$. gariepinus and Tilapia species is practiced. A poly-culture of $C$. gariepinus and Oreochromis niloticus, integrated with poultry with some supplementary feeding had been shown to be viable.

African catfish exhibits considerable growth variation both under aquaculture and in the wild (Van der Waal, 1998). The causes of such variation are still not clear, although it has been suggested that inherent differences in feeding behaviour may contribute to this variation (Valente et al., 2001; Sundström et al., 2003; Martins et al., 2005 Aderolu et al., 2011).

The African catfish is especially known to exhibit sophisticated forms of social feeding behaviour, where the dominant fish are observed to exclude the subordinates from getting a relatively greater proportion of the food (Hecht and Uys, 1997). This phenomenon is thought to be a major cause for the feeding growth variations among individuals ( $\operatorname{Rad}$ et al., 2004).

According to Thornton et al. (1979) and Adewumi and Olaleye (2011), animals subjected to a period under nutrition often exhibit very high growth during subsequent re-alimentation. This phenomenon is known as compensatory growth. In manipulative feeding experiments, food available to an individual fish can be restricted in two different ways: (1) by decreasing the amount of food within a feeding period or (2) by decreasing number of times of feeding. The latter case is adopted in this experiment.

The theory underlying compensatory growth is that an animal that has experienced a period of feed restriction will exhibit a hyperphagic response upon satiation feeding, resulting in faster growth (Russell and Wootton, 1992). Compensatory growth is of interest in aquaculture because an understanding of its dynamics may allow for the design of feeding schedules that could further improve growth rates (Hayward et al., 1997).

Feed and feeding practices can have significant effects on catfish production cost and hence the profitability of catfish farming. Under normal conditions catfish should typically be fed daily as much feed as they will consume without adversely affecting water quality. However, depending on water temperature, other water quality parameters and the health of the fish, it may be prudent to restrict the daily feed allowance or to feed less frequently. How much to feed and the frequency of feeding are decisions that must be made daily by catfish producers based on each fish pond. Feed and feeding of catfishes in grow out ponds are perhaps the most documented in literature (Ayinla, 1988; Adewumi, 2005; Alegbeleye et al., 2008; Oresegun et al., 2007; Olukunle, 2009).

The objectives of this study were to examine the effect of various feeding frequencies on the growth performance, nutrient utilization and economic analysis of previously starved catfish fingerlings and juveniles that were later subjected to satiation feeding.

\section{MATERIALS AND METHODS}

\section{Experimental fish, diet and husbandry conditions}

The present study was conducted in concrete ponds (each WITH $25 \mathrm{~m}^{2}$ surface area) located at EL-Serow Fish Farm, National Institute of Oceanography And Fisheries, Dukhlia Governorate, Egypt. These ponds were firstly drained and cleaned, then supplied with drainage freshwater from El-Serow drainage canal to a depth of 0.8-1.0m. The experimental period lasted for 4 months (over a period of 10 weeks before satiation feeding resumed for 12 weeks). Prior to the commencement of this 
experiment, African Catfish, Clarias gariepinus, fingerlings and juveniles (with average weight of $8.5 \pm 0.1$ and $34.3 \pm 0.1 \mathrm{~g}$ respectively) were obtained from a local farm and transferred into plastic tanks and left to acclimatize to experimental conditions for two weeks in aN experimental ponds fitted to a flow-through system . They were kept under natural conditions and fed a popular commercial catfish feed (Table1) of size 3.0 to $4.0 \mathrm{~mm}$, subjecting them to four different feeding frequencies: Fed once (at 11:00 h), twice (at 9:00 and 16:00 h), thrice (at 9:00, 13:00 and 16:00 h) and four times $(9: 00,11: 00,13: 00$ and 16:00 h) daily respectively to apparent satiation with each feeding frequency in triplicates for 12 weeks after which they were all fed thrice daily (9:00, 13:00 and 17:00 h) to apparent satiation for another 14 weeks before the commencement of the experiment.

The treatments were designated F1, F2, F3, F4, J1, J2, J3 and J4, respectively based on fish size (fingerlings, F and juveniles, J) and feeding frequencies (1-4) accordingly. Feed remains were measured for each pond every other week to determine the actual quantity of feed taken using a digital scale (Camry EK5055 Max $5 \mathrm{~kg} / 11 \mathrm{lb} \mathrm{d}=1 \mathrm{~g} / 0.05 \mathrm{oz}$ ) and recorded. All Fish were also weighed individually at the beginning and end of the experiment, while batch weighing per pond was performed weekly using a digital scale to monitor growth performance.

Table 1: Nutrient composition of the popular commercial feed (\% DM).

\begin{tabular}{|l|l|}
\hline Content & \% \\
\hline Crude protein & 42 \\
\hline Carbohydrate & 13 \\
\hline Crude fibre & 1.50 \\
\hline Ash & 9.00 \\
\hline Calcium & 1.60 \\
\hline Phosphorus & 1.10 \\
\hline Lysine & 2.80 \\
\hline Methionine & 0.90 \\
\hline Selenium & $0.3 \mathrm{mg} / \mathrm{kg}$ \\
\hline
\end{tabular}

Fish ponds were cleaned daily by draining some pond water out residual feed and faecal matter. Water in the ponds were changed twice weekly depending on how dirty the water gets and mortalities were removed and recorded. Water quality parameters (temperature, dissolved oxygen and $\mathrm{pH}$ ) were monitored twice weekly. Temperature with Mercury-in-glass thermometer calibrated in degree centigrade $\left({ }^{\circ} \mathrm{C}\right)$, dissolved oxygen (DO) was determined by using the Winkler's solution and $\mathrm{pH}$ was determined with a $\mathrm{pH}$ meter, to ensure they were within tolerant limits expected for the studied species. During the experiment, water temperature, $\mathrm{pH}$ and dissolved oxygen (DO) were kept within $27-29^{\circ} \mathrm{C}, 8.4-8.9$ and 5.5-6.8 mgL-1 respectively. This was achieved from the source of water used for the experiment which was from a drainage freshwater from El-Serow drainage canal.

\section{Calculations}

Growth was expressed as mean weight gain $(\mathrm{g})$, relative weight gain, and specific growth rate. Nutrient utilization indices were expressed as voluntary feed intake, feed conversion ratio and protein efficiency ratio as follows:

Mean weight gain $(\mathrm{MWG})(\mathrm{g})=\mathrm{Wf}-\mathrm{Wi}$,

Relative growth rate $(\mathrm{RGR})=($ Weight gain $/$ Initial body weight $) \times 100$

Specific growth rate $(\mathrm{SGR})(\mathrm{g})=(\log \mathrm{w}-\log \mathrm{wI} / \mathrm{t}) \times 100$

Voluntary feed intake $(\mathrm{VFI})(\%)=100 \times \mathrm{FI} /[(\mathrm{Wi}+\mathrm{Wf}) \times \mathrm{t}]$

Where:

Wf refers to the mean final weight; 
Wi is the mean initial weight of fish, and

$\mathrm{T}$ is the feeding trial period in days.

Feed conversion ratio $(\mathrm{FCR})=$ Feed Intake $(\mathrm{FI})$ (dry weight in $\mathrm{g}$ ) /Fish wet weight gain $(\mathrm{g})$

Protein efficiency ratio $($ PER $)=$ Mean weight gain $/$ Total Protein intake

Where: Protein Intake $=$ Total feed intake $/$ Protein content of feed.

\section{Economic analysis}

The economic analysis was performed to estimate the cost of feed required to raise a kilogram of fish (for both fingerlings and juveniles) fed the popular commercial feed while being cultured under controlled conditions. The cost of feed and fish were the only economic criteria under consideration in this case and were based on the current market cost of the commercial feed and market value of a kilogram of fresh fish in Egypt at the time of the experiment. The economic evaluations in terms of gross profit (GP), net profit value (NPV), investment cost analysis (ICA) and incidence cost (IC) were calculated based on the method of New (1996) as follows:

Gross profit $(\mathrm{GP})=$ Net profit value $(\mathrm{N})-$ Investment cost analysis $(\mathrm{N})$

Net profit value $(\mathrm{NPV})=$ Mean weight gain of fish cropped $(\mathrm{g}) \times$ Total no of the survival (n) x cost per $\mathrm{kg}$

Investment cost analysis $(\mathrm{ICA})=$ Cost of feed $(\mathrm{N})+$ Cost of fishstocked $(\mathrm{N})$

Incidence of cost $(\mathrm{IC})=$ Cost of feed $(\mathrm{N}) /$ mean weight gain of fish produced $(\mathrm{g})$

\section{Statistical analyses}

The experimental design was a complete randomised design. All data collected were subjected to analysis of variance (ANOVA). Data are reported as mean \pm standard error $(n=5)$. Comparisons among treatment means were carried out by Duncan Multiple Range test (Duncan, 1955) at a significance level of $\mathrm{P}<0.05$. All computations were performed by the statistical package SPSS 15.0 (SPSS Inc., Chicago, IL, USA).

\section{RESULTS AND DISCUSSION}

The mean growth performance, nutrient utilization and economic analyses of the fingerlings and juveniles stages of fish on four different feeding frequencies now fed to apparent satiation are shown in Tables( 2 and 3), respectively.

The initial weight of the fish at the point of commencement of this trial for the fingerlings and juveniles stages ranged from 42.91 - 87.60 and $101.63-119.73 \mathrm{~g}$ respectively while the final weight of the fingerlings and juveniles stages ranged from 265.03 - 390.22 and $373.67-511.00 \mathrm{~g}$, respectively at the end of the trial (Tables 2 and 3 , respectively). It means that the mean life weight of all groups increased over the period they underwent apparent satiation (12 weeks). There was a significant difference $(\mathrm{P}<0.05)$ in both initial and final weight of both the fingerlings and juveniles groups.

A gradual increase in mean weight was obvious for each treatment per period over the period of 12 weeks of apparent satiation feeding. This could be as a result of adaptation of fish to change in feeding frequency. 
Table 2: Growth performance, nutrient utilization and economic indices of Clarias gariepinus fingerlings stage of previously starved fish now fed to satiation thrice daily.

\begin{tabular}{|c|c|c|c|c|c|}
\hline \multirow[t]{2}{*}{ Parameters } & \multicolumn{5}{|c|}{ Experimental treatment } \\
\hline & 1 & 2 & 3 & 4 & $\pm \mathrm{SE}$ \\
\hline Mean initial weight (g/fish) & $42.91 \mathrm{~b}$ & $72.12 \mathrm{a}$ & $84.73 \mathrm{a}$ & $87.6 \mathrm{a}$ & \pm 132.98 \\
\hline Mean final weight (g/fish) & $265.03 \mathrm{c}$ & $358.35 \mathrm{ab}$ & $390.22 \mathrm{a}$ & $294.08 b c$ & \pm 1694.83 \\
\hline Mean weight gain (g/fish) & $222.12 b$ & $286.23 \mathrm{ab}$ & $305.49 \mathrm{a}$ & $206.48 \mathrm{c}$ & \pm 32.37 \\
\hline Relative weight gain (\%/fish) & 58.75 & 54.99 & 47.92 & 27.5 & \pm 6.69 \\
\hline Specific growth rate (\%/day) & $0.99 \mathrm{~b}$ & $1.07 \mathrm{~b}$ & $0.89 \mathrm{ab}$ & $0.69 \mathrm{a}$ & \pm 0.17 \\
\hline Average feed intake (g/fish) & 244.86 & 257.50 & 265.19 & 227.19 & \pm 606.29 \\
\hline Feed conversion ratio & 1.64 & 0.76 & 0.89 & 1.46 & \pm 0.20 \\
\hline Voluntary feed intake (g/fish) & 13.66 & 7.21 & 7.84 & 8.80 & \pm 1.21 \\
\hline Protein intake & 6184.2 & 6715.0 & 7037.9 & 5442.2 & \pm 312.98 \\
\hline Protein efficiency ratio & 0.05 & 0.06 & 0.06 & 0.05 & \pm 0.003 \\
\hline Net profit value $(\mathrm{N} / \mathrm{kg})$ & 13.35 & 12.3 & 29.03 & 24.18 & \pm 3.77 \\
\hline Investment cost analysis $(\mathrm{N})$ & $263.46 a$ & $320.58 b$ & $336.22 b$ & $324.83 b$ & \pm 10.46 \\
\hline Incidence cost & 0.05 & 0.04 & 0.04 & 0.05 & \pm 0.001 \\
\hline Gross profit/loss (N) & $160.11 \mathrm{a}$ & $218.28 b$ & $217.2 \mathrm{~b}$ & $210.65 b$ & \pm 8.78 \\
\hline
\end{tabular}

All values on the same row with the different superscripts are significantly difference $(\mathrm{P}<0.05)$.

Table (3) shoud that, the specific growth gate (SGR) exhibited clear fluctuations ranging from 0.69 to 1.0 with overall mean values of $0.99,1.07,0.93$, and $0.69 \%$ in diets $1,2,3$ and 4 respectively for the fingerlings stage, while for the juveniles stage were from $0.93,0.84,0.73$, and $0.63 \%$ in diets $1,2,3$, and 4 , respectively (Tables 2 and 3). The growth data clearly indicated that the final live weight values of the third treatment for the fingerlings and juveniles stages, F3 and J3, were significantly higher than those of other treatments $(\mathrm{P}<0.05)$ but it varied in the SGR, as the second treatment for fingerlings stage, F2, was significantly higher than those of other treatments (Table 2).

Feed conversion rate (FCR) was presented in Table 2. The best (the lowest mean) FCR was obtained from fed twice (F2) in the fingerlings and juveniles stages (Tables 2 and 3).

Table 3: Growth performance, nutrient utilization and economic indices of Clarias gariepinus juvenile stage fed the same type of feed.

\begin{tabular}{|c|c|c|c|c|c|}
\hline Parameters & & Experim & I treatmen & & \\
\hline & 1 & 2 & 3 & 4 & \pm SE \\
\hline Mean initial weight (g/fish) & $101.63 a$ & $116.37 \mathrm{a}$ & $119.73 a$ & $113.75 \mathrm{a}$ & \pm 135.78 \\
\hline Mean final weight (g/fish) & 373.67 & 425.1 & 511.0 & 439.81 & \pm 1794.53 \\
\hline Mean weight gain (g/fish) & 272.04 & 308.73 & 391.27 & 326.06 & \pm 26.61 \\
\hline Relative weight gain (\%/fish) & $35.85 b$ & $25.6 a b$ & $18.15 \mathrm{a}$ & $20.95 a$ & \pm 2.56 \\
\hline Specific growth rate (\%/day) & $0.93 \mathrm{a}$ & $0.84 \mathrm{ab}$ & $0.73 \mathrm{ab}$ & $0.63 \mathrm{~b}$ & \pm 0.05 \\
\hline Average feed intake (g/fish) & $256.42 b$ & $253.17 \mathrm{~b}$ & $292.12 \mathrm{a}$ & $279.89 \mathrm{ab}$ & \pm 606.30 \\
\hline Feed conversion ratio & 0.97 & 0.79 & 1.09 & 1.48 & \pm 0.27 \\
\hline Voluntary feed intake (g/fish) & 7.36 & 5.85 & 6.72 & 7.52 & \pm 0.75 \\
\hline Protein intake & $6569.0 \mathrm{~b}$ & $6433.0 \mathrm{~b}$ & $8069.4 \mathrm{a}$ & $7555.4 \mathrm{ab}$ & \pm 292.35 \\
\hline Protein efficiency ratio & 0.03 & 0.04 & 0.03 & 0.03 & \pm 0.01 \\
\hline Net profit value $(\mathrm{N} / \mathrm{kg})$ & 37.57 & 55.3 & 49.68 & 24.81 & \pm 8.06 \\
\hline Investment cost analysis $(\mathrm{N})$ & 406.93 & 425.95 & 437.64 & 393.97 & \pm 8.94 \\
\hline Incidence cost & 0.01 & 0.01 & 0.01 & 0.01 & \pm 0.001 \\
\hline Gross profit/loss (N) & 279.36 & 280.65 & 297.96 & 279.15 & \pm 10.50 \\
\hline
\end{tabular}

All values on the same row with the different superscripts are significantly difference $(\mathrm{P}<0.05)$. 
Considering the economic analysis, in the fingerlings group, there was a significant difference with the feeding frequency in the fish fed once (F1) from the other treatments in the investment cost analysis (ICA) and the gross profit (GP).

African Catfish (C. gariepinus) fingerlings and juveniles were subjected to different daily feeding frequencies and brought to thrice daily feeding frequency to check their recovery. The highest weight gain was obtained $(\mathrm{P}<0.05)$ by feeding the fingerlings fish (twice daily) and the juvenile fish (thrice daily), thus providing more feed. It is evident that a higher growth rate depends on both higher and more frequent daily feed uptake. Studies conducted on other fish species have shown that feed consumption and growth generally increased with feeding frequency up to a given limit (Wang et al., 1998; Başçinar et al., 2007). This is in agreement with our findings in this study that feeding frequency had a significant effect on feed consumption and growth in the African catfish.

Food conversion ratio was best in twice daily feeding frequency because of its lowest food conversion ratio ( 0.76 and 0.79$)$ value when compared to other treatments for the fingerlings and juvenile stages, respectively. Once daily feeding frequency with the highest food conversion ratio value (1.64) for the fingerlings stage and four times daily with the highest food conversion ratio value (1.48) for the juveniles stage were the poorest in food conversion. This may have been responsible for the best growth performances observed in the fish fed twice daily for both stages. According to De Silva and Anderson (1995); Adewumi and Olaleye (2011); Aderolu et al., (2011), when these fish are fed to satiation, they do not tend to eat again until the stomach is almost completely evacuated. Therefore, feeding frequency of twice daily is often more than sufficient.

The ability of an organism to utilize nutrients especially protein will positively influence its growth rate (Sogbesan and Ugwumba, 2008; Adewumi and Olaleye, 2011; Aderolu et al., 2011). This is justified by the highest PER and low FCR in the treatments fed twice daily in the fingerlings and juveniles fish stage. This suggested that fish must have efficiently converted feed consumed to growth.

The economical analysis of the feed for the fish fed once daily, twice daily, thrice daily and four times daily to satiation showed that both the cost of the feed and gross profit in treatment fed twice daily at the fingerling stage and treatment fed thrice daily were the best. In this situation, it is recommended that the treatment fed twice and thrice daily were the best economically for catfish.

Knowledge of how feed restriction affects the growth rate of catfish under different production conditions could be of practical value to producers seeking to develop feeding strategies that provide greater economic flexibility in an environment of changing feed costs and fluctuating fish prices.

This present study showed that all the different feeding frequencies experimented upon can be used to feed $C$. gariepinus juvenile stage. Feed restriction should be avoided in the fingerlings stage of $C$. gariepinus growth because fish recovery rate was better in the juvenile stage compared to the fingerlings stage when exposed to satiation feeding.

\section{REFERENCES}

Aderolu, A. Z.; Lawal, M. O.; Seriki, B. M. and Apatira, A. L. (2011). Compensatory growth effects on previously starved fingerlings and juveniles of African catfish (Clarias gariepinus, Burchell 1822). African J. Food Sci., 5(11): 637-642. 
Adewumi A. A.1 and Olaleye V. F. 2 (2011). Catfish culture in Nigeria: Progress, prospects and problems. African J. Agricult. Res., 6(6):1281-1285.

Adewumi, A A. (2005). The effects of the heating time of soybean for the broodstock nutrition on the reproductive performance of C. gariepinus (Burchell 1822), 162p.

Alegbeleye WO., Obasa BO, Olugbenga O, and Ramoni N. (2008). Effect of feeding Colocasia esculenta (L) corn flour as part of energy supplement on growth and nutrient utilization in Clarias gariepinus fingerlings.Conference Proceedings of the Fisheries Soc. Of Nigeria (FISON), J. Autqa; Balogun J.K.; P.I. Bolorunduro and H.U. Onimisi (Eds.) Kaduna, 2008, p. 88-93.

Ayinla O.A. (1988). Nutritive and Reproductive Performance of Clarias gariepinus (Burchell 1822). Unpublished Ph. D Thesis, University of Ibadan, Nigeria, 433p.

Başçinar, N.; Çakmak, E.; Çavdar, Y. and Aksungur, N. (2007). The effect of feeding frequency on growth performance and feed conversion rate of Black sea trout (Salmo trutta labrax Pallas, 1811). Turk. J. Fisheries and Aquatic Sci., 7: 13-17.

De Groot, S.J. (1987). Culture of Clarias species. Elsevier Science Publishers, Amsterdam, 366 pp.

Duncan, DB. (1955). Multiple range and multiple F tests. Biometrics, 11: 1-42.

De Silva SS. and Anderson, TA. (1995). Fish Nutrition in Aquaculture. Chapman and Hall Aquaculture series, London, $319 \mathrm{p}$.

Egborge, ABM and Chigbu, P. (1988). The Rotifers of Ikpoba River, Bendel State. The Nigerian Field, 53: 117-132.

FAO (2007). (Food and Agriculture Organization of the United Nations). Fishstat Plus. FAO, Rome.

Khallaf, E. A. and Gaber, N. (1991). Analyses of stomach contents and intraspecific interaction over diet of Clarias lazera (Cuv.\&Val.) in Bahr-Shebeen canal. Bulletin of Faculty of Science Zagazig Univ., 13(2):481-499.

Hayward, R. S.; Noltie, D. B. and Wang, N. (1997). Use of compensatory growth to double hybrid sunfish growth rates, Trans. Am. Fish. Soc., 126: 316-322.

Hecht, T. and Uys, W. (1997). Effect of density on feeding and aggressive behavior in juvenile Africa catfish, Clarias gariepinus. South African J. Sci., 93: 537-541.

Martins, CI.; Schrama, JW. And Verreth, JA. (2005). Inherent variation in growth efficiency of African catfish Clarias gariepinus (Burchell 1822) juveniles. Aquac. Res., 36: 868-875.

New, M.B. (1996). Responsible use of aquaculture feeds. Aquacult. Asia, 1: 3-15.

Olaleye, VF. (2005). A review of reproduction and gamete management in the African catfish, C. gariepinus (Burchell). Ife J. Sci., 7(1): 63-70.

Olukunle, AO. (2009). Utilization and growth response of Clarias gariepinus fingerlings fed varying inclusion levels of livestock vitamin grower's premix. Conference Proceedings of the Fisheries Soc. of Nigeria (FISON), O.A. Fagbenro, O.A. BelloOlusoji; E.O. Adeparusi;, L.C. Nwanna; A.A.Dada \& M.O.Olufayo (Eds.), Akure 2009, pp.169- 173.

Oresegun, A.; Oguntade, OR. and Ayinla, OA. (2007). A review of catfish culture in Nigeria. Nig. J. Fish., 4(1):27-52.

Osuji, CN.; Ockiya, JA. and Chinda, AC. (2003). Dominance shift of phytoplankton in relation to different organic fertilizer treatment in Clarias gariepinus culture. In: A. A Eyo, J.O Ayanda (eds). Conference Proceedings of Fisheries Society of Nigeria (FISON). Owerri $8^{\text {th }}-12^{\text {th }}$ December, 2003, pp. 62-66.

Ovie, SI. (1996). Raising zooplankton for food larval and post larval stage of fish in hatcheries. NIFFR Extension Guide, Series No.5.

Pillay, T.V.R. (1990). Aquaculture: Principles and Practices. Fishing News Books, London, $575 \mathrm{pp}$. 
Rad, F. Kurt, G. and Bozaoglu, S. (2004). Effect of spatially localized and dispersed patterns of feed distribution on the growth, size dispersion and feed conversion ratio of the African catfish clarias ga. Turk. J. Vet. Anim. Sci., 28: 851-856.

Russell, NR and Wooten, RJ. (1992). Appetite and growth compensation in the European minnow, Phoxinus phoxinus (Cyprinidae), following short periods of food restriction, Environ. Biol. Fish., 34: 277-285.

Sogbesan, AO. And Ugwumba, AAA. (2008). Nutritional evaluation of termite Macrotermes subhyalinus. Meal as animal protein supplements in the diets of Heterobranchus longifilis fingerlings. Turk. J. Fish. Aqua. Sci., 8: 149-157.

Solomon, J.R. and Boro, S.G. (2010). Survival Rate In Poly Culture of Catfish Heteroclarias /Tilapia (Oreochromis Niloticus), Fed 2\% Body Weight New York Sci. J. 2010; 3(9).

Sundström, LF.; Devlin, RH.; Johnsson, JI. and Biagi, CA. (2003). Vertical position reflects increased feeding behaviour in growth hormone transgenic coho salmon (Oncorhynchus kisutch), Ethol., 109: 701-712.

Thornton, RF.; Hood, RL.; Jones, PN. and Re, VM. (1979). Compensatory growth in sheep. Austr. J. Agr. Res., 30: 135-151.

Valente, LMP.; Saglio, P.; Cunha, LM. and Fauconneau, B. (2001). Feeding behaviour of fast-and slow-growing strains of rainbow trout, Oncorhynchus mykiss (Walbaum) during first feeding, Aquac. Res. 32: 471-480.

Van der, W.B.C.W. (1998). Survival strategies of sharptooth catfish Clarias gariepinus in desiccating pans in the northern Kruger National Park Koedoe - African Protected Area Conservation and Science, 41: 131-138.

Wang, N.; Hayward, R.S. and Noltie, D.B. (1998). Effect of Feeding Frequency on Food Consumption, Growth, Size Variation, and Feeding Pattern of Age-0 Hybrid Sunfish. Aquacult., 165: 261-267.

\section{Arabic Summary}

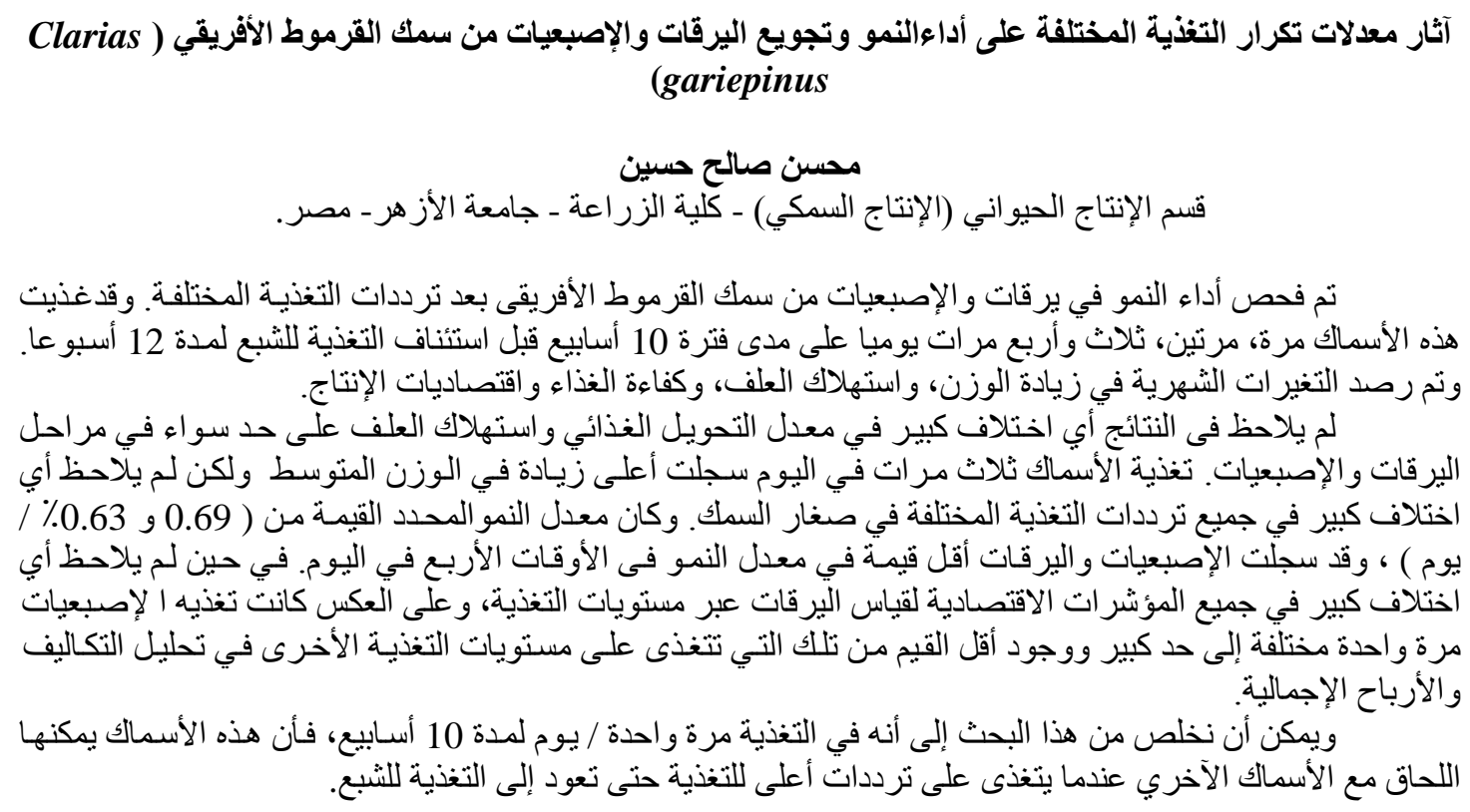

